(RESEARCH ARTICLE)

\title{
Systematic inventory of the colopterological population of the rice plants of Gharb (Morocco)
}

\author{
Berady karim*, Maqboul Abdelaziz, Aoujdad Rabia and Fadli Mohamed \\ Laboratory of Biodeversity and Animal Ressoureces, Ibn Tofail University, B.P 133, 14000, Kenitra, Morocco
}

Publication history: Received on 11 July 2018; revised on 17 August 2018; accepted on 25 August 2018

Article DOI: https://doi.org/10.30574/gscbps.2018.4.3.0064

\begin{abstract}
Due to favorable climatic and soil conditions, Moroccan rice cultivation is practiced entirety in the lowest region of the Gharb plain. The systematic study of the colopterological group at ten stations covering all the rice fields during 2015 and 2016 rice periods revealed a great diversity in comparison with other similar environments. The 39 species were sampled belonging to 12 families with a predominance of predation species. The biogeographically analysis of this entomofauna reveals prevalence of the Mediterranean species which has relation with the location of the Gharb plain in protected area from Saharan influence. Finally, the biotypological study of this colopterological group during the two cycle's season's highlights the individualization of three groups of species organized in a continuum around the two level factorial of PCA: species with summer, fall development and species which sampled throughout the rice growing season.
\end{abstract}

Keywords: Coleopteran; Systematic; Biotypology; Ecology; Rice fields; Gharb plain (Morocco)

\section{Introduction}

Rice cultivation is considered to be the world's second largest crop in terms of area and production. Indeed, it occupies a floor area of about 160 million hectares with an estimated world production of 598 million tons of paddy per year in 2002.In Morocco, rice cultivation is practiced exclusively in the lowest part of the Gharb plain because of the favorable climatic and soil conditions offered by this area as well as the richness of its water network [1]. Currently, the rice potential of this plain is around 4500 hectares [2].The yield achieved in 2014 is close to 80 quintals per ha, which exceeds that recorded in the countries specialized in this agricultural production. It would even exceed the European average. The colopterological stand of rice fields in the Gharb plain (Morocco) is almost entirely of vital interest in controlling the number of organisms living at the expense of the rice plant in particular aphids, leafhopper nymphs and stem borers, and can thus be described as useful insects in Moroccan rice fields.

The systematic study of this order of insects was carried out on the Moroccan rice fields during the 2015 and 2016 rice growing seasons accompanied by an identification of certain other species which have very close trophic links with the studied group. The aim of this study is to establish an inventory of the fauna of Colopterology in the Gharb plain rice fields and its distribution during a crop cycle; to highlight its role in the control of pest populations and finally the biogeographic analysis of this stand.

\footnotetext{
${ }^{*}$ Corresponding author

E-mail address: karimberady@gmail.com
}

Copyright (C) 2018 Author(s) retain the copyright of this article. This article is published under the terms of the Creative Commons Attribution Liscense 4.0. 


\section{Material and methods}

\subsection{Location of the study area}

The Gharb plain (figure 1) is located in the Atlantic littoral zone between latitudes $34^{\circ}$ and $34^{\circ} 45$ 'N. Its hydrogeographical area is $7500 \mathrm{~km}^{2}$ [3]. It presents a wide range of soil. Starting from Oued Sebou, we find the Dehs, the Shots and the soils of Merjas respectively, pH slightly alkaline. The climate is Mediterranean, Very rich in water resources (Sebou River and its tributaries, Merjas and groundwater).

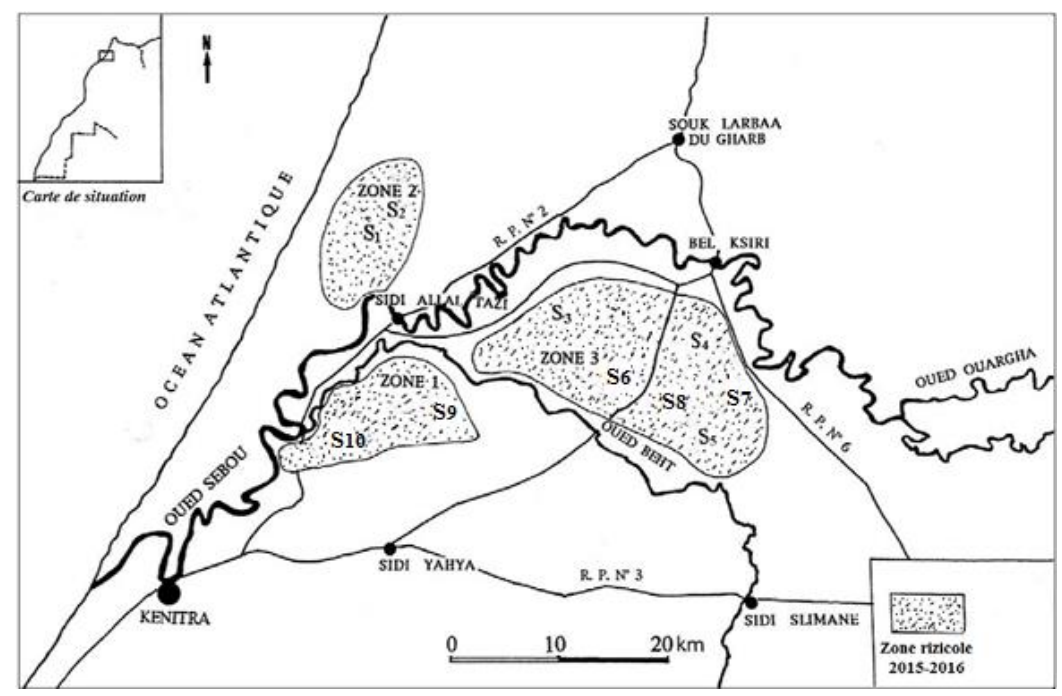

Figure 1 Gharb plain and the study stations location

\subsection{Operation and maintenance of rice fields}

The ground works begin in May-April. Rice is sown within 10 days after submersion. The survey period lasts 35 to 40 days. It is only during the month of June that each foot produces many stems (tillering). Vegetative growth continues in July (upstream) followed by flowering at the end of the month and heading in August. It takes 170 days for the rice to reach maturity. The rice field is dry in mid-September and the harvest is usually in October. The development cycle of this crop takes place between May and October.

Since this crop is totally irrigated, it consumes a lot of water. Its field consumption is estimated at $17400 \mathrm{~m}^{3} / \mathrm{ha}$ [4]. It corresponds to the compensation of evapotranspiration needs, evaporation of the water body, drainage and infiltration of water into the soil.

\subsection{Methods of sampling}

Sampling techniques in rice fields are similar to those recommended in shallow environments (ponds) [5-7] and generally adapted in the sampling of héléoplancton at rice fields [8].

The idea is to delimit with a hollow cylinder with sharp edges (40 cm diameter during the first two months of submersion in the absence of a macro-intense vegetation and $20 \mathrm{~cm}$ diameter at the rice stage) a volume of water to collect all the fauna present in the water-sludge column.

The samples are taken from ten stations covering the three rice areas of the Gharb plain during the 2015 and 2016 rice growing seasons. At each station, we made two samples at shallow depths and two others at great depth (edges of the rice field) with a frequency of two monthly readings. So we made qualitative samples using a fine meshed net.

\subsection{Inventory of harvested species}

After deposition of the chamber in the sediment, its water content is recovered, then filtered using a fine-mesh plankton net $(0.3 \mathrm{~mm})$. Similarly, a slice of sediment or can house Benthic forms are removed and rinsed 2 to 3 times. The filtrate is then stored in a $10 \%$ formalin solution. 
Specific determinations were made using original descriptions, European keys and collections from the Rabat Institute of Science (Morocco).

Table 1 List of species of the Coleopteran Oder

\begin{tabular}{|c|c|c|}
\hline Suborder & Family & Species \\
\hline \multirow[t]{5}{*}{$\begin{array}{l}\text { Adephaga }=\text { Coleoptera } \\
\text { Hydrocanthares }\end{array}$} & Dytiscidae & $\begin{array}{l}\text { Hydrovatus clypealis SHARP, } 1876 \\
\text { Yola bicartina LATREILLE, } 1804 \\
\text { Guignotus pusillus FABRICIUS, } 1781 \\
\text { Laccophilus minutes LINNE, } 1758 \\
\text { Laccophilus hyalinus DE GEER, } 1774 \\
\text { Rhantus pulverosus STEPHENS, } 1828 \\
\text { Ertes stictucus LINNE, } 1767 \\
\text { Dytiscus pisanus CASTELNAU, } 1834 \\
\text { Cybister lateralimarginalisDE GEER, 1774- } \\
\text { Copelatus atriceps SHARP, } 1880 \quad\end{array}$ \\
\hline & Noteridae & Noterus leavis STURN, 1834 \\
\hline & Haliplidae & Pletodytes caesus DUFTSCHMID, 1805 \\
\hline & Gyrinidae & Gyrinus substriatus STEPHENS, 1828 \\
\hline & Carabidae & $\begin{array}{l}\text { Calatus ambiguous PAYKULL, } 1790 . \\
\text { Harpalus affinis SCHRANK, } 1781 . \\
\text { Pseudoophonus rufipes DE GEER, } 1774 . \\
\text { Poecilus cupreus LINNE, } 1758 . \\
\text { Anchomenus dorsalis PONTOPPIDAN, } 1763 . \\
\text { Carabus auratus LINNE, } 1761 . \\
\text { Brachinus sp. WEBER, } 1801 . \\
\text { Pterostichus melanarius ILLEGER, } 1798 .\end{array}$ \\
\hline \multirow{7}{*}{$\begin{array}{l}\text { Polyphaga }=\text { Coleoptera } \\
\text { Palpicornes }\end{array}$} & Hydraenidae & Ochtebius sp. LEACH, 1815 \\
\hline & Helophoridae & Helophorus aquaticus LINNE, 175 \\
\hline & Hydrophillidae & $\begin{array}{l}\text { Berosus hispanicus KUSTER, } 1847 \\
\text { Berosus suturalis KUSTER, } 1844 \\
\text { Helochares lividus FORSTER, } 1771 \\
\text { Enochrus affinis THUNBERG, } 1797 \\
\text { Enochrus fuscipennis THOMSON, } 1884 \\
\text { Paraccymus aeneus GERMAR, } 1824 \\
\text { Celostoma hispanicum KUSTER, } 1848 . \\
\text { Cercyon sp. LEACH, } 1817 .\end{array}$ \\
\hline & Curculionidae & $\begin{array}{l}\text { Lissorhoptrus oryzophilus KUSCHEL, } 1951 \\
\text { Nanophyes nitidulus GYLLENHALL, } 1838 \\
\text { Sitophilis oryzae LINNE, } 1763\end{array}$ \\
\hline & Elmidae & Oulimnius maurus BERTHELEMY, 1979 \\
\hline & Chrysomélidae & $\begin{array}{l}\text { Timarcha scabripennis LATREILLE, } 1839 \\
\text { Lachnaia octomaculata PIC, } 1895 \\
\text { Chaetocnema sp. STEPHENS, } 1831\end{array}$ \\
\hline & Coccinelidae & Coccinella septempunctata LINNE, 1758 \\
\hline
\end{tabular}




\section{Results and discussion}

The purpose of this inventory is to enhance taxonomic knowledge of Coleoptera zoological group in Moroccan rice fields. The biodiversity shows that the colopterological group of the Gharb plain ricefields is much diversified in comparison with the number of taxon of the same group harvested in the rice fields of Camargue (France) [9]. These 39 species distributed over 12 families form a banal and classical taxonomic composition of the shallow environments of the littoral zones and the lakes. However there are representative species typical of this ecosystem, it is the case of the Carabidae, Chrysomelidae, Curculionidae and Coccinellidae.

In addition, among the most faunistic results from this study is the discovery for the first time of a number of taxon that have not been the subject of previous citations. We mention the species of Lissorhoptrus oryzophilus, Nanophyses nitidulus and Sitophilus oryzae.

Composition of the colopterological Moroccan ricefields based on the chorological categories established by La Greca attributed to each taxon according to its area of occupation [10], shows that it consists essentially by Mediterranean elements $(44,7 \%)$, followed by palearctic distribution $(29,4 \%)$ and species with a wide geographical distribution $(25,8 \%)$ (Figure 2).

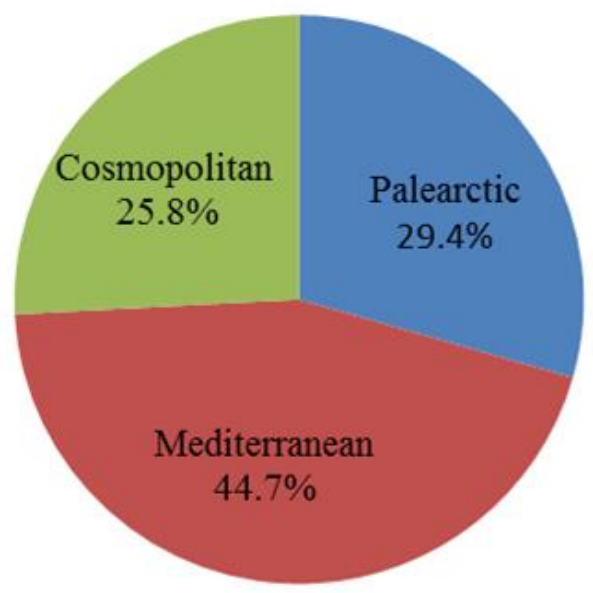

Figure 2 Categories of the colopterological group

This analysis shows that Mediterranean Europe appears richer than North Africa, both in number of species and number of endemic species. This would be due to the isolation of North Africa from Europe at the end of the tertiary and desertification of the Sahara in the quaternary [11]. These two phenomena have constituted a biogeographic barrier to the fauna of Europe and Africa. These results are similar during the study of the benthic population of the Moulouya watershed (Morocco) [12].

In addition, interspecific relationships based on bibliographic data reveals the predominance among this population of predatory species that are characterized by active behavior, which allows them to hunt large numbers of prey. Except of Imago of Hydrophilidae and Haliplidae, Coleoptera Chrysomelidae and Curculionidae are considered phytophagous [13-18] which the majority of species have carnivorous habits. So they can fight against the outbreaks of organisms that can cause damage to this crop. Thus, these predators can be considered as aids to this crop, and therefore contribute to biological control that occurs spontaneously in the ricefield, especially in places where there is no use of a wide range of pesticides. In addition, many species among this group have a mixed diet, which ensures greater diversity and stability in the community.

In order to look for the spatiotemporal evolution of the Coleopopera population of the Moroccan rice fields during the two rice seasons 2105 and 2016, we used the correspondence factorial analysis. This statistical method is widely used, by several authors $[7,8,17,19-21]$ to analyze the structuring of lentic and lotic environments.

Distribution of the species subjected to this multivariate analysis highlights the individualization of three main groups of species around the factorial plane F1 x F2, which are organized in a continuum in the same direction as the seasonality gradient statements. This analysis had shown the presence of species with summer and autumnal development and spreading species along the culture cycle (Figure 3). 


\subsubsection{Group 1: Summer species development}

This is the case of Dytiscidae. E. sticticus known for its great carnivorous power, frequenting calm waters rich in aquatic vegetation $[13,22]$ and with an abundance of soft prey composed mainly of larvae of Diptera; Chironomidae.

Other species in this group P. caesus and P. aeneus are considered as phytophagous [23], in particular at the larval stage which are most often associated with the characeae in addition to their preference for waters with high mineralization rates, especially for $P$. aeneus $[15,23]$.

\subsubsection{Group 2: Autumnal species development}

For the colopterological population, we can highlight a first group represented by the Coleoptera Hydrocanthares (C. atriceps, L. hyalinus, $N$. leavis, C. ambiguus, A. dorsalis and P.melanarius). They are described as excelent predators of aphids, leafhopper nymphs and stem borers which abound during this period, in addition to their preference for areas rich in aquatic vegetation and decomposing organic matter, particularly for representatives of the family Carabidae and the Dytiscidae [5, 23-24]. The second group is represented by the species L. oryzophilus, considered as phytophagous, devastating plants of rice [25] According to the Chrysomelid (L. octamaculata) compared to its highly polyphagous behavior [26], its presence at this stage would be related to the abundance of prey of all kinds at that time.

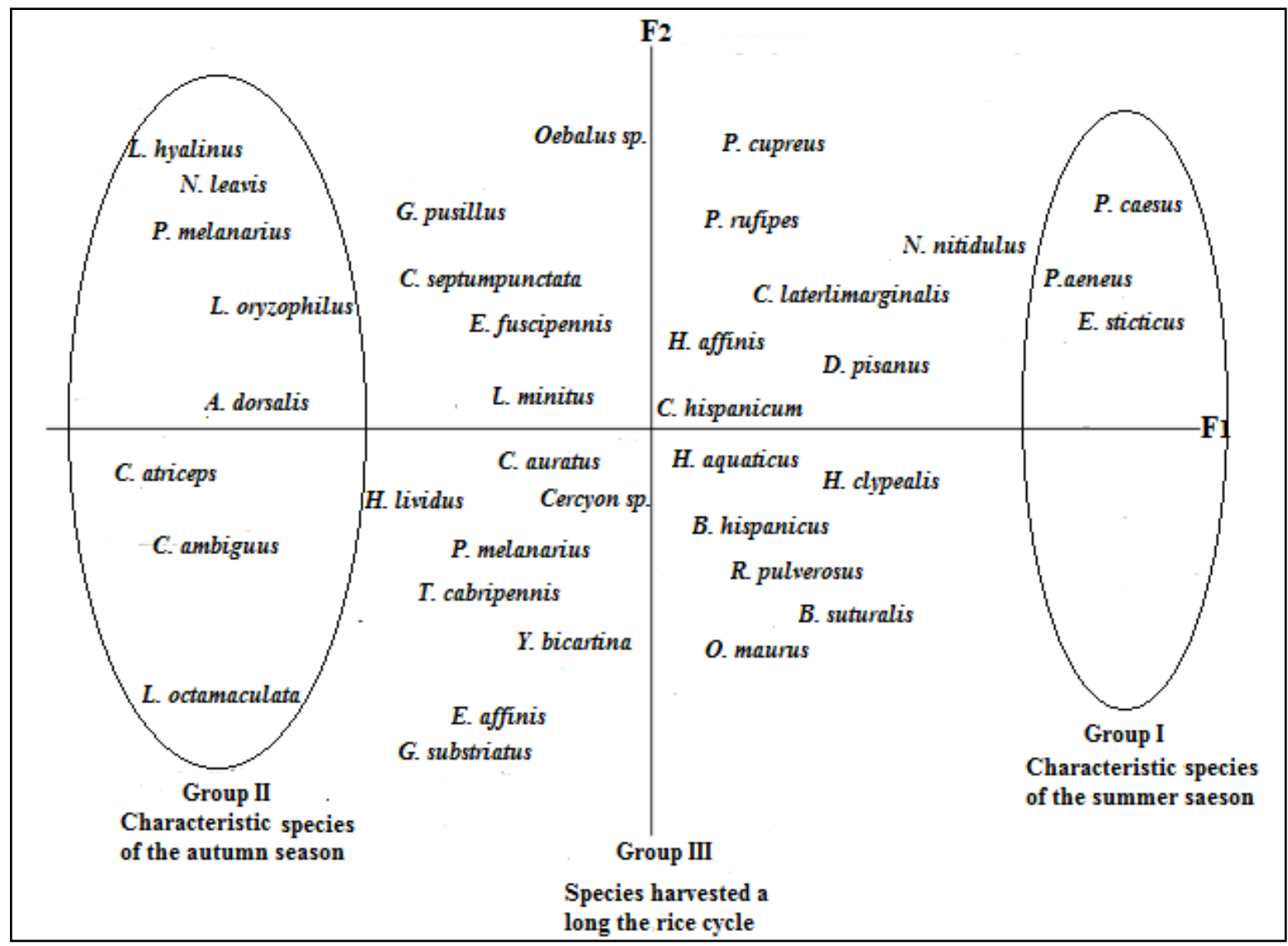

Figure 3 Biotypology structure in the factorial plane $\mathrm{F}_{1} \mathrm{X} \mathrm{F}_{2}$

\subsubsection{Group 3: Species with spreading development}

Between these two characteristic groups of the summer and autumn season distribution, many species are usually present throughout the rice field practice. This intermediate group is constituted by the Coleoptera: Hydrocanthares which are known as voracious carnivorous predators. The primary consumers who serve them as food are in direct relation with the vegetable biomass of the rice fields $[5,13]$. It therefore seems obvious to relate their presence to certain types of plants, especially those that will directly serve as food such as filamentous algae, Characeae and probably Oryza sativa present throughout the rice cycle. This plant cover also plays a supporting role for these species which are bad swimmers. 
On the other hand, $N$. nitidulus is known by its plants pest, especially at the stem part of the plant [16], the ladybug $C$. septempunctata, well known for its use in biological control, because it is predatory in the larval and adult stages [17]. Its prey is the small insects: aphids, mealy bugs, whiteflies, Diptera and Lepidoptera larvae (caterpillars). They can also eat insect eggs $[27,28]$. They are therefore entomophagous predators, active during the day and frequenting the top half of the rice plants.

Finally, O. maurus is considered as characteristic of lotic environments of freshwaters [12]. Its presence in the rice fields is linked to the phenomenon of the natural drift of these organisms from irrigation water, where the favorable conditions for its reproduction are meeting.

\section{Conclusion}

The taxonomic study of the colopterological group of the rice fields of the Gharb plain (Morocco) shows that it is very diversified in comparison with other similar environments despite of the short period of the rice cycle. This agricultural ecosystem has 39 species spread over 12 of the most representative families of this group. It is essentially composed by Mediterranean taxon, followed by species whose distribution extends to the palearctic domain and finally species with a wide geographical distribution. On the other hand, due to their pronounced predatory power, most of the listed species contribute to a significant biological control by controlling the outbreaks of insects harmful to rice. The biotypological study has highlighted the individualization of three main groups of species around the factorial plane F1 X F2: summergrowing species grouped on the positive pole of the F1 axis; species with autumnal development, distributed on the negative pole and finally the grouping of spreading species along the culture cycle. It is therefore clear from this study that this stand of insect constitutes a real means of biological control at the level of the rice fields. Indeed, it is essential to preserve by reducing the use of the pesticides in an anarchic way which have harmful consequences on the environment and useful wildlife.

\section{Compliance with ethical standards}

\section{Acknowledgments}

The authors are thankful to Mrs. Aouad, professor at the University of Fes, for her very strong contribution and collaboration during the identification of the species.

\section{Disclosure of conflict of interest}

All authors declare that they have no conflict of interest.

\section{References}

[1] Boulet C and Bouhache M. (1990). Floristic, biological and weed diversity of rice weeds in Gharb (Morocco). Proceedings, Hassan II Agronomic and Veterinary Institute, Rabat, Morocco, 10 (2), 5-24.

[2] Anonyme. (1974). Rice, report of the Gharb Regional Agricultural Development Authority. Ministry of Agriculture and Agrarian Reform, 8-13.

[3] Combe E. (1969). Hydrogeological map of the Gharb plain 1/100000. Notes and Memoirs. Service Geology. Morocco, 221 bis, 35-36.

[4] Lahlou 0. (1989). Rice growing in Gharb: current situation and prospects. Report of the study day on the constraints related to Moroccan rice cultivation and current methods of genetic improvement of rice. IbnTofail University, Kenitra, Morocco, 15 April 1989, 22-56.

[5] Ramdani M. (1981). Hydro biological researches on the Merja of Sidi Boughaba (Atlantic coast of Morocco), Physico-chemical study and faunistic analysis. Bulletin Institut Scientifique, Rabat, Morocco, 5 (12), 73-133.

[6] Himmi 0. (1991). Culicidae (Diptera) from Morocco. Updated key of determination and study of the dynamics and the biological cycles of some populations of the Rabat-Kenitra region. Doctoral thesis, Mohamed V University, Rabat, Morocco, 100-125.

[7] Berady K. (1997). Bio-ecological research on the entomological settlement of rice fields in the Gharb plain (Morocco). Doctoral thesis, Ibn Tofail University, Kenitra, Morocco, 152-158. 
[8] Aoujdad R. (1996). Ecological and systematic research on Cladoceran crustaceans from the Gharb plain (Morocco). Doctoral thesis, Ibn Tofail University, Kenitra, Morocco, 105-115.

[9] Viala M. (1978). First elements of macrofauna stand and Odonata (Ischnaura elegans) populations in shallow environments. Diploma of Advanced Studies, U.S.T.L., Montpelier, France, 50-56.

[10] Aukema P and Reiger C. (1995). Catalogue of the Heteroptera the palaearctic Region. Journal of the Netherlands Entomlogical Society, 5(12), 189-222.

[11] Louanci A. (2014). Fourth Franco-Maghreb congress of zoology and fifth Franco-Tunisian days of Korba-Tunisia zoology (13-17 November 2014).

[12] Lamri D, Hassouni T, Loukili A, Belghyti D and Chahlaoui A. (2016). Contribution to the knowledge of Coleoptera (Coleoptera) of the Moulouya hydrographic network (Morocco). Journal of Faunistic Entomology, 69 (10), 97109.

[13] Aouad N. (1984). Ecological study of Hydrophiloidae of stagnant waters of the Rabat region (Coleoptera: Palpicornes). Doctoral thesis, Paul Sabatier University, Toulouse III, France, 112-116.

[14] Aguilar RM. (2001). Research stratégies for rice developement in transition economies. Cahiers Options Méditerranéens, 50 (8), 123-126.

[15] Queney P. (2005). French maritime locations, new or confirmed, for Hygrotus (Coelambus) nigrolineatus (STEVEN, 1808) and Pallidulus (AUBE, 1850), Metaporus meridionalis (AUBE, 1838), Octhebius bifoveolatus (WALTL, 1835) (Coleoptera: Dytiscidae and Hydraenidae). Le Coléoptériste, 8 (2), 138-139.

[16] Delbol M. (2012) Presence in Belgium of Dieckmanniellus nitidulus (GYLLENHAL, 1838) (Coleoptera: Curculionoidae Nanophyidae) and identification key for Nanophyidae species. Journal of Faunistic Entomology, 65 (3), 105-117.

[17] Rafarasoa LS, Ranarilalatiana T, Andrianantoandro A. and Ravaomanarivo LH. (2015). Biodiversity of the entomofauna of rice paddies in the Alaotra Lake region (Madagascar). Journal of Malagasy Nature, 9 (11), 15-38.

[18] Essakhi D, El harchli EH, Benjelloun M, Maazouzi M, Mansouri I, Azouzi A and El ghardaoui L. (2015). Contribution to the study of the diet of Orthoptera Locusts in the Middle Atlas (Morocco). International Journal of Engineering and Science, 5 (12), 60-66.

[19] Dakki M. (1986). Hydrological research on the Upper Sebou (Middle Atlas): a contribution to the fauna, ecological and historical knowledge of the South Mediterranean waters. Doctoral thesis, Mohamed V University, Rabat, Morocco, 188-192.

[20] Fekhaoui M. (1990). Hydrobiological research on the Upper Sebou subjected to rejects of the city of Fez; followed by macro-pollution and assessment of its richness on the physical, chemical and biological components of the ecosystem. Doctoral thesis, Mohamed V University, Rabat, Morocco, 162-173.

[21] Maqboul A. (1996). Biological and ecological research on the malacological fauna of the Gharb plain (Morocco). Doctoral thesis, Ibn Tofail University, Kénitra, Morocco, 142-151.

[22] El Alaoui A. (1985). Contribution to the ecological study of Coleoptera Hydrocanthares of the Moroccan coastal meseta. Ph. D. Thesis, Mohamed V, Rabat University, Morocco, 115-122.

[23] Bloechel A, Koenemann S, Philipi B. and Melbert, A. (2010). Abundance, diversity and succession of aquatic Coleoptera and Heteroptera in a cluster of artificial ponds in the North German Lowlands. Journal of Limnologica - Ecologiy and Management of Inland Waters, 40 (3), 215-225.

[24] Baranovska J, Knapp E, and Saska P. (2014). The effects of everwintering sex, year, field identity and vegetation at the boundary of fields on the body condition of Anchomenus dorsalis (Coleoptera: Carabidae). Eurpeen Journal Entomolgy, 111 (5), 608-614.

[25] Lupi D, Colombo M, Giudici ML, Villa B, Sparacino AC and Ranghino F. (2007). Present status of knowledge on Lissorhoptrus orysophilus. Fourth inetrnational Temperate Rice Conference, 2007, 138-139.

[26] Beenen R and Roques A. (2010). Leaf and seed beetles (Coleoptera, Chrysomelidae). Chapter 8.3. In: Roques A et al, Alien terrestrial arthropods of Europe. Journal of Biorisk, 4(1), 267-292.

[27] Hemptine JL, Magro A. and Majerus M. (2005). Ladybugs, description, cohabitation, observation. Delachaux and Nestle edition, Paris, France, 160-162. 
[28] Magro A, Le compte E, Magne F, Hemptine JL and Crouau-roy B. (2010). Phylogeny of ladybirds (Coleoptera: Coccinellidae) are the sub-families monophyletic. Journal of Molecular phylogenetics and evolution, 54 (3), 833-848.

\section{How to cite this article}

Berady K, Maqboul A, Aoujdad R and Fadli M. (2018). Systematic inventory of the coleopterological population of the rice plants of Gharb (Morocco). GSC Biological and Pharmaceutical Sciences, 4(3), 29-36. 